\title{
The Influence of Modern English Loanwords on the Verbal Code of Russian Culture
}

\author{
Yulia M. Alyunina ${ }^{1}$ and Olga V. Nagel ${ }^{2}$ \\ ${ }^{1}$ RUDN University \\ Moscow, Russia \\ ${ }^{2}$ National Research Tomsk State University \\ Tomsk, Russia
}

\begin{abstract}
The aim of the article is to introduce the authors' perspective on how English loanwords are changing the structure and the content of the verbal code of Russian culture and the Russian linguistic pictures of the world, as well as on how the latter might change the former. Having used the continuous sampling method, observation method, and synchronic-diachronic approach (lexical semantic analysis, comparative semantic analysis, morphological and quantitative analysis), the authors have allocated and analyzed 487 loanwords, which led to the introduction of three distinguished types of interaction between the verbal code of the Russian language and foreign loanwords. The first interaction type is the process whereby the loanwords adapt semantically to the rules of the host language and culture, which leads to the complete change of a loanword meaning or its modification (15 words). The second interaction type is connected with the loanwords bringing new concepts to a host language and indicating borrowed ideas and objects ( 270 words). The differentiation of these two interaction types is based on the results of a synchronic and diachronic study of the loanwords in Russian. The analyzed interaction types are linked to the changes in the host language's verbal code. A concept of a "hybrid linguistic picture of the world" is being introduced as the one constituting the third interaction type (201 words). According to the authors, the hybrid linguistic picture of the world is developing at the current stage of the Russian language and is caused by the process of the morphological adaptation of English loanwords, which is manifested in the production of hybrid words and Russian words being actively substituted by English borrowings.
\end{abstract}

Keywords: loanwords, Anglicisms, verbal code, hybrid linguistic picture of the world

For citation:

Alyunina, Yulia M. and Olga V. Nagel. 2020. The influence of modern English loanwords on the verbal code of Russian culture. Russian Journal of Linguistics 24 (1). 176-196. DOI: 10.22363/2687-0088-2020-24-1-176-196. 
Научная статья

\title{
Влияние современных английских заимствований на вербальный код русской культуры
}

\author{
Ю.М. Алюнина ${ }^{1}$, О.В. Нагель ${ }^{2}$ \\ ${ }^{1}$ Российский университет дружбы народов \\ Москва, Россия \\ ${ }^{2}$ Национальный исследовательский Томский государственный университет \\ Томск, Россия
}

\begin{abstract}
Аннотация
Цель статьи - описать происходящие под влиянием англоязычных заимствований изменения в структуре и содержании вербального кода русской культуры и русской языковой картины мира, а также влияние языковой картины мира на изменение вербального кода. Методы сплошной выборки и описания, а также синхронно-диахронный подход в исследовании (лексико-семантический анализ, сравнительно-семантический анализ, морфологический и количественный анализ) позволили обнаружить 487 заимствований и выделить три выраженных типа взаимодействий между русским языковым кодом и иностранными заимствованиями. Первый тип представляет семантическую адаптацию заимствований к правилам принимающего языка и культуры, что приводит к полному изменению значения заимствуемого слова, или его модификации (15 заимствований). Второй тип взаимодействия связан с заимствованиями, которые привносят в принимающий язык новые понятия, называющие заимствованные идеи и объекты (270 заимствований). Выделение данных типов взаимодействия основывается на результатах синхронно-диахронного изучения функционирования заимствованной лексики в русском языке. Рассматриваемые типы взаимодействия положены в основу проблематики сохранения и изменения вербального кода культуры принимающего языка. Третий тип взаимодействия (201 заимствование) представлен в понятии гибридной языковой картины мира, которая, по мнению авторов, складывается на современном этапе развития русского языка как следствие активного процесса адаптации англицизмов и проявляется в возникновении слов-гибридов и замене русских эквивалентов англицизмами.
\end{abstract}

Ключевые слова: заимствования, англицизмы, вербальный код, гибридная языковая картина мира

\section{Для цитирования:}

Alyunina, Yulia M. and Olga V. Nagel. 2020. the Influence of modern English loanwords on the verbal code of Russian culture. Russian Journal of Linguistics 24 (1). 176-196. DOI: 10.22363/2687-0088-2020-24-1-176-196.

\section{Introduction}

In research studies loanwords are discussed by many Russian (Krysin 2008, Khalevin 2010a, 2010b, Serebrennikova 2014, Rivlina 2015 etc.) and international scholars (Haugen 1950, Poplack, Sankof \& Miller 1988, Veisbergs 2006, Jaworski 2014 etc.) who mainly focus on the problem of the formal and semantic adaptation of borrowings to the recipient language revealing changes of a loaned word's meaning as well as their structural assimilation. The issue of English loanwords and their influence on the modern Russian language has become topical within the last decade and is being discussed by Krysin (2008), Levontina, Shmelev \& Zaliznjak 
(2012), Vorob'eva (2009), Klement'eva (2014) et al. One of the major problems in scope is the nature, rules and consequences of the interaction of new words with the cultural linguistic picture of the world (hereinafter - LPW). Thus scholars' interest shifting from the study of purely "sign to sign interaction" to the study of "sign culture" domain.

According to Tolstoi (1995) language and culture have "certain features of structural similarity" with a language being a "verbal code of culture" (Lukin 2015: 65-66) which expresses the worldview of a language community through language units. The overall aim of the present study is to discuss the role of loanwords in their contribution to the change in a verbal code of culture and the ability of the language affected to preserve and exercise its objectives to express a culturally conditioned worldview, and to determine basic patterns of interaction between the loanwords and the recipient language, which are either determined by a linguistic picture of the world of the recipient Russian language or lead to its change.

Aligned with the statement above, the main objectives in this study are as follows: (1) to specify a verbal code of culture; (2) to specify the interaction patterns between a recipient language's linguistic picture of the world and loanwords; (3) to discuss the influence of modern English loanwords on the verbal code of the recipient language and culture.

Lexical examples included in the study are based on the authors' observations, retrieved from linguistic landscape, dictionaries of loanwords in Russian, Russian LiveJournal blog posts, RNC (hereinafter - Russian National Corpus) or taken from secondary sources (see the References) and, thus, represent proof-checked lexical material existing in the Russian language. The number of analyzed LifeJournal texts to find loanwords is 280 (173 434 words). The number of retrieved loanwords is 304 words (4 951 entries). The rest of the loanwords were taken from secondary sources and linguistic landscape -183 words. RNC and dictionaries were used to allocate the found loanwords semantics and the contexts of usage. Based on the examples obtained through continuous sampling and observation and the results of their synchronic-diachronic study (lexical semantic analysis, comparative semantic analysis, morphological and quantitative analysis) the authors speculate on the role English loanwords play in the lexical structure of the modern Russian language as well as on the part they play in the construction of a cultural verbal code.

\section{Theoretical backgroun}

The terminological apparatus of the research is mainly based on Russian language studies and requires closer determination to disclose the main aspects of the present research. A code is commonly referred to as "a combination of signs (symbols) and a system of certain rules by which information can be represented (encoded) as a set of such symbols for its transmission, processing, and storage (memorization)" (Bol'shoj Jenciklopedicheskij Slovar' 1993). Every code consists of elements or signs which should be organized in a proper way for the code to implement its functions. Svetlana Tolstaya (2007), who leads the Moscow Ethnolinguistic 
School named after Lev Tolstoi, highlights three essential characteristics of a code: substantial homogeneity, systemacity and conventionality.

Substantial homogeneity is the characteristics of a code, which means that the code consists of qualitatively equal elements that serve to express the same idea by completing each other. For example, music consists of notes (hymn, alarm), a visual code consists of objects (traffic signs) or colors (state flag), a verbal code consists of meaningful linguistic elements of the same language (morphemes make words, words make phrases, phrases make sentences). Systematicity stands for the way the elements of a code organize themselves: colors make up a color spectrum, traffic light colors make up a traffic regulation system, letters make up an alphabet, and words make up a language's lexicon. Conventionality stands for the feature that each element of a code has a meaning which is subscribed to it. We use a code to convey (encode) information. A recipient is able to decode the information because helshe knows the meaning prescribed to the code elements: an embroidery scheme, pattern for knitting, flower language, sign language, any living language. Thus, a combination of signs can be called a code when it consists of equal elements, has a systemic organization and is recognized by an addressee.

According to Tolstoi (1995), every culture has a code for self-expression, which consists of several other codes (or subcodes): a corporal code, a musical code, acoustic, color, gesture codes etc. A verbal code is also a constituent of a cultural code, the most complicated one and the most important as each of the cultural code constituents can be expressed through the verbal code thanks to a nominative function of the language. Thus, following Tolstoi (1995), "language is a tool of a culture" (1995: 36), and a verbal code of a culture is "any form of a language (word, term, name, cliché, proverbs, folklore text, saying, curse, ritual words etc.)" (Tolstaya 2007) which can express cultural information of this language community by means of its structural elements.

Language is a type of a code that "represents culturally constructed conceptualizations encompassing the whole range of human experience" (Sharifian 2017: 2). In other words, language features are embedded in cultural conceptualizations, and through the language we can express our worldview. Thus, the verbal code of a culture is the ability of a language with its structural elements to express the cultural specifics of a language speaking community.

Structural elements of a language (phonemes, morphemes, words) are responsible for this ability; "language can be viewed as a primary mechanism for "storing" and communicating cultural cognition, acting both as a memory bank and a fluid vehicle for the (re-)transmission of cultural cognition" (Sharifian 2017: 5). In other words, a language preserves and expresses cultural conceptualizations by means of language structural elements. To make up a complete picture of the world by means of a language all language elements are used, because each of them correlates with a part of the world or with a part of our attitude to the world.

On the phonetic level, the cultural conceptualizations by means of language structural elements can be demonstrated by onomatopoetic words, which copy the 
sounds around. In some languages they are alike, but in others they are very different:

- Sound of a kiss: Russ. члок [chmoc] ${ }^{1}$; Eng. smooch, smack; Fin. musik.

- Dog barking: Russ. гав-гав [gav gav], тяф-тяф [tyaf tyaf]; Fr. ouah ouah, Eng. bow wow.

- Sound of a frog: Russ. ква-ква [kva-kva]; Eng. croak; Danish kvoek kvoek.

The difference in onomatopoetic words depends on many factors, among which is the way people hear the sounds and the way they can reproduce them, distinguishing the most precise and typical phonemes for this or that object of reality.

Concerning the morphemic level, according to (Nagel 2015: 227), word-formation models have the status of a "cultural code" that helps people to express their worldview via morphological units. Historically, in Slavic culture suffixes transmit the attitude of speakers to the abnormalities in human bodies and human behavior, including verbal. Slavic culture had a tradition to nickname people according to their origin, their roles in the community, their appearance or character, etc. In Slavic languages among the suffixes used for this purpose there were -ah ([zubaha] - зубаха - Eng. pejorative), -ok ([pochinok] - починок - Eng. firstborn), -un ([godun] - годун - Eng. sluggish), -an ([molchan] - молчан Eng. silent) and others. These examples are no longer used in Russian, however the meaning of the suffixes is preserved and they are used to form other lexical units with the same socio-cultural semantics: [govorun] - Russ. говорун - Eng. babbler, [znatok] - Russ. знаток - Eng. expert, [golovan] - Russ. голован - Eng. know-all. Thus, word-formation models represent a "language objectification of the way a person perceives and structures information, pointing out the most important meanings for social interaction" (Nagel 2015: 227).

On lexical and syntactic levels, the cultural code of a language can be expressed through proverbs and sayings. These are culturally consolidated and closed units of a language: no word can be substituted by another one. Despite many Russian proverbs and sayings including words which are not used in the modern language, they correspond to modern life and express the cultural peculiarities and mentality of a Russian linguistic community: Russ. Баба с возу - кобыле легче Eng. A good riddance to bad rubbish; Russ. - В Тулу со своим самоваром не ездяm; Eng. - They don't bring coals to Newcastle. Only words which have a connection with the corresponding culture can be used to express the cultural code of a language in syntactical units of this kind. The influx of loanwords complicates the connection between the culture expressive syntactical units and the host LPW, because loanwords represent a foreign LPW.

Besides, in Russian, the cultural code of the language can be expressed purely syntactically by traditional syntactic constructions. Syntax is not just a formal organization of linguistic units, "it also encodes a certain type of conceptualization,

\footnotetext{
${ }^{1}$ Hereinafter we use the online transliteration service recommended by the Journal in section
} 2.5. of the guide for authors: https://translit.ru/ru/?account=bsi. [Last viewed: 20.07.2019]. 
and by learning this (of course, not only this), a person is familiarized with a cultural worldview" (Mel'nikova 2006: 34). Among syntactical constructions in Russian, there are fixed patterns that are called "syntactical concepts" (Popova 2004: 27), because by their syntactical forms they express the worldview and reflect the LPW. In this research, we follow the syntactical concepts discussed by Popova (2004). In Slavic languages, as well as in Russian, one of them is the concept of "the statement of the subject absence" (Popova 2004: 29) which is fashioned with the use of a noun or a pronoun in genitive form, the word no (Russ. [net]), an adverbial modifier of place and no explicit predicate: Russ. Этой книги нет в библиотеке - Eng. This book is not in the library; Russ. Оиенки нет в тетради - Eng. There is no mark in the copybook; Russ. Eё нет в комнате - Eng. She is not in the room. According to Popova, in English and in German there is no such concept as "the statement of the subject absence"; that is why in these languages constructions of existence are used with a verb and the particle no: Eng. There is no...; Germ. Es gibt ... nicht.

Another example is a syntactic concept of "existence with the meaning of possessiveness" (Popova 2004: 29), which is expressed in Russian with the use of an object in the possessive in combination with the verb to have: Russ. У него есть красный автомобиль. - Eng. Hе has a red car; Russ. У неё есть свободное время на этих выходных - Eng. She has free time this weekend. The grammatical subject is not explicit in this syntactical construction. German and English sentences with the same meanings are constructed with the grammatical subjects and grammatical predicates with the latter expressed by the verb to have: Eng. He has a cat - Germ. Er hat eine Katze. In Russian, the grammatical construction $y$ него/неё/них есть (Eng. she/he has, they have) is frozen which means that the verb does not coordinate with the possessing object whether singular or plural, unlike in German or in English.

Thus, the language code of a culture can be traced on each language level: phonetic, morphological, lexical and syntactic. We claim that loanwords also can be included in each of the language levels and become either the means of the verbal code expression or the means of its change.

By appearing in a recipient language, loanwords bring new linguistic fragments of cultural conceptualization, which undergo stages of assimilation (orthographic, grammatical, and semantic) before they enter the recipient language's lexical structure. Some loanwords adapt to a recipient language and lose their foreign appearance, but some of them make the recipient language adapt to them. These new language elements can change the verbal code of the recipient culture.

The ability of a language to serve as the verbal code of a culture is supplied by cumulative and world-image constructive functions (Vereshchagin 1980, Serebrennikova 2014). Though it is assumed that all language levels are involved in the representation, fixation and preservation of information about reality, the vocabulary level is regarded as one of the most essential for the cumulative function. The cumulative function is responsible for the preservation (accumulation) of the cultural heritage in a language (Vereshchagin 1980), thereby turning a language into a sort of a memory bank (Sharifian 2017). Each unit of a language preserves a part of 
the culture where this language exists. Lexical units are the most cumulative in this sense, being the most visible units that preserve a verbal image of a concept or an object that belongs to a language community holistically, and are easily accessed by all members of this community.

The world-image constructive function is responsible for "conceptualizing the world by means of a language" (Serebrennikova 2014: 196). The world around, according to Serebryannikova (2014), is understood as "the interaction of a human and the environment, which the human is conceptualizing, learning and structuring" (Serebrennikova 2014: 196). Another way to explain the world-image constructive function is to describe it as the language function that makes us see the world in the way we are "verbalized" to see it. This statement can be exemplified by the following: in Russian, there is a word окно [okno] (Eng. window) which has its origin in the Ancient Russian око [oko] that stands for an eye (Shaposhnikov 2010: 64-65). In English, a window has its origin in the Middle English windowe or earlier in the Old Norse vindauge, where vindr is wind and auga stands for an eye (MerriamWebster Dictionary). Thus, we can conclude, that for Russian speakers [okno] is something through which we can see and thus it performs the same function as human eyes (metonymic transfer), while for English speakers, window is something through which we can see (metonymic transfer) with an additional component to the meaning: to see the wind. This example represents the difference in our worldviews (in our world pictures) determined by the language we speak and the culture which stands behind it. On the one hand, the culture is imprinted in words by determining their meanings, and, on the other hand the culture is preserved by words which can tell about the culture in the past (archaisms, historicism).

With the rapid increase of loanwords, the implementation of cumulative and world-image constructive functions becomes more loaded due to the possible involvement of loanwords in this process. On the one hand, each language adjusts to the changes in the surrounding world to reflect events and phenomena occurring in the sociocultural space in each individual period of its development and the employment of new words is a natural process. On the other hand, if the language as the verbal code of a culture accepts foreign language elements, then both the recipient language and the culture have to transform in a number of ways. Since languages are different in "how they encode reality" (Nagel \& Koshkarova 2015: 728-729) or create its linguistic picture, thus, when languages establish a close contact, one of the results of which are borrowings, there arises the problem of changes in the original image of a culture as a cultural LPW starts its interaction with the borrowed units.

This interaction might lead both to the change of the verbal code of a culture through the replacement of the usual language elements by the borrowed ones, and to the loanwords' conceptual adaptation to the recipient language.

\section{Loanwords and recipient language interaction types}

In this section we proceed to the principal part of the study and discuss the interaction types between a recipient language LPW with loanwords and the 
influence of modern English loanwords on the change of the verbal code of the Russian language and Russian culture revealed by the synchronic and diachronic study of loanwords in Russian.

The first interaction type is the semantic adaptation of loanwords to the rules of the recipient language and culture, which results in a loanword meaning transformation. The second interaction type is connected with loanwords that indicate ideas and objects borrowed by the recipient culture, thus bring new semantic units to the host language and culture. The third subsection is devoted to the third interaction type allocated in the result of the study. In the third interaction type we include the loanwords that do not bring new semantic components to the recipient language but adapt to the host-language grammatically and substitute the existing lexical ways to express meaning. The result of the third interaction type is discussed through the prism of the "hybrid linguistic picture of the world" that raises the issue of changes in the Russian language's verbal code which either accepts loanwords into its system (completely assimilated words) or lets them function as foreign elements preserving some traits of their source language form and meaning.

It is a well-known fact that loanwords undergo different types of assimilation in a host-language. The main types of assimilation are orthographic, grammatical, and semantic, which also have their subtypes. Orthographic assimilation is the adaptation of a borrowed word to the orthographic system of a host-language (Lisogub 2004, Nechaeva 2011: 11, Gabdreeva \& Ageeva 2014: 224). Grammatical assimilation means that the loanwords adapt to the grammatical rules of the recipient language: adaptation to the declination and word-formation patterns (Vorob'eva 2009: 179). Semantic assimilation means that a recipient language "loans all semantic components of a loanword's lexical meaning (denotative, significate, connotative, ethnocultural)" (Gabdreeva \& Ageeva 2014: 224) with its further semantic adaptation resulting in either semantic expansion or restriction. The above-mentioned ways of assimilation take place during the first and second interaction types, but during the third interaction type there is the rejection of semantic adaptation though loanwords that undergo grammatical assimilation.

\subsection{First Interaction Type}

The first interaction type shows all types of a loanword assimilation: orthographic, grammatical, and semantic. The semantic assimilation during this type of interaction is the most distinct as the original meaning of a loaned lexical unit is partially or completely lost. Consequently, a loan word does not stand out as an alien word but looks and sounds common for the host-language speakers. Thus, this interaction type results in the loanwords changing or modifying their semantics under the influence of the LPW of the recipient language which accepted a loanword and transformed its meaning to its own requirement.

Semantic change is regarded as the semantic assimilation of a borrowing when in a recipient language it has a completely different meaning in comparison with its original one. Examples of such semantic assimilation are presented in Table 1. 
Examples of semantic changes of foreign loanwords in Russian

\begin{tabular}{|c|c|c|c|c|}
\hline $\begin{array}{l}\text { Source lan- } \\
\text { guage }\end{array}$ & $\begin{array}{l}\text { Original } \\
\text { form }\end{array}$ & Original semantics & $\begin{array}{c}\text { Cyrillic and } \\
\text { transliteration }\end{array}$ & Russian dictionary definition \\
\hline Persian & sarāi & castle & сарай [sarai] & $\begin{array}{l}\text { "Non-living premises for keeping } \\
\text { garden working tools". (TSOO) }\end{array}$ \\
\hline French & fourchette & fork & вилка [vilka] & $\begin{array}{l}\text { "Small standing party or reception } \\
\text { with drinks and canapés". (TSOO) }\end{array}$ \\
\hline French & vinaigrette & $\begin{array}{l}\text { "Cold sauce made with } \\
\text { vinegar, oil and season- } \\
\text { ing" (CD) }\end{array}$ & $\begin{array}{l}\text { винегрет } \\
\text { [vinegret] }\end{array}$ & $\begin{array}{l}\text { 1. "Cold salad made of chopped } \\
\text { vegetables and sauced with vine- } \\
\text { gar, oil, and herbs"; } \\
\text { 2. colloq. "A mix of unordered } \\
\text { thoughts or mismatched objects". } \\
\text { (Shaposhnikov 2010a: 117) }\end{array}$ \\
\hline \begin{tabular}{|l|} 
French \\
Polish
\end{tabular} & $\begin{array}{l}\text { honneur; } \\
\text { honor }\end{array}$ & pride & гонор [gonor] & Arrogance. (TSOO) \\
\hline German & $\begin{array}{l}\text { Der Gas- } \\
\text { tarbei-ter }\end{array}$ & guest worker (DUDEN) & $\begin{array}{l}\text { lacmapбaй- } \\
\text { mep [gastar- } \\
\text { bait-er] }\end{array}$ & $\begin{array}{l}\text { "In modern Russia, a worker from } \\
\text { the former Soviet Union republics } \\
\text { and South-East Asia". (Slovar'Aca- } \\
\text { demic) }\end{array}$ \\
\hline English & notebook & a book for notes & $\begin{array}{l}\text { Hoymбук } \\
\text { [noutbuk] }\end{array}$ & Laptop. \\
\hline English & lifting & $\begin{array}{l}\text { 1. "The action of ending } \\
\text { a rule or law" } \\
\text { 2. "The action of moving } \\
\text { something from a lower } \\
\text { to a higher position" } \\
\text { (CD) }\end{array}$ & $\begin{array}{l}\text { лифртинг [lift- } \\
\text { ing] }\end{array}$ & Face-lift. \\
\hline
\end{tabular}

Modification of meaning is a semantic transformation of a lexical unit with the original semantics of a loaned word to be partially preserved. Examples are presented in Table 2.

Examples of semantic modifications of foreign loanwords in Russian

Table 2

\begin{tabular}{|c|c|c|c|c|}
\hline $\begin{array}{l}\text { Source } \\
\text { language }\end{array}$ & $\begin{array}{l}\text { Original } \\
\text { form }\end{array}$ & Original semantics & $\begin{array}{l}\text { Cyrillic } \\
\text { and tran- } \\
\text { scription }\end{array}$ & Russian semantic \\
\hline German & $\begin{array}{l}\text { n. Die } \\
\text { Schlange }\end{array}$ & $\begin{array}{l}\text { 1. } n \text {. snake; } \\
\text { 2. } n \text {. hosepipe, hose tube. (Shaposhnikov } \\
\text { 2010: } 545 \text { ) }\end{array}$ & $\begin{array}{l}\text { шланд } \\
\text { [shlang] }\end{array}$ & $\begin{array}{l}n \text {. Hosepipe, } \\
\text { hose tube. } \\
\text { (Shaposhnikov } \\
\text { 2010: } 545 \text { ) }\end{array}$ \\
\hline French & n. cadet & $\begin{array}{l}\text { 1. adj. junior (in a family, in the army); } \\
\text { 2. } n \text {. "a student of a school with military } \\
\text { training" ("élève, aspirant officier") (Diction- } \\
\text { naire français en ligne gratuit). }\end{array}$ & $\begin{array}{l}\text { kadem [ca- } \\
\text { det] }\end{array}$ & $\begin{array}{l}\text { n. "A student of a } \\
\text { military school". } \\
\text { (TSOO) }\end{array}$ \\
\hline French & n. baiser & $\begin{array}{l}\text { 1. } v \text {. to kiss. } \\
\text { 2. } n \text {. a kiss }\end{array}$ & безе [beze] & $\begin{array}{l}\text { 1. n. Meringue; } \\
\text { 2. n., old. A kiss. }\end{array}$ \\
\hline
\end{tabular}




\begin{tabular}{|l|l|l|l|l|}
\hline $\begin{array}{c}\text { Source } \\
\text { language }\end{array}$ & $\begin{array}{c}\text { Original } \\
\text { form }\end{array}$ & \multicolumn{1}{|c|}{ Original semantics } & $\begin{array}{c}\text { Cyrillic } \\
\text { and tran- } \\
\text { scription }\end{array}$ & Russian semantic \\
\hline English & adj. nude & $\begin{array}{l}\text { 1. Naked, without clothes. } \\
\text { 2. Tone of clothes or make-up, the colors } \\
\text { that are close to natural skin colors. (OLD) }\end{array}$ & Hюdoвый & Equal to 2. \\
\hline English & n. look & $\begin{array}{l}\text { 1. A noun, meaning an action derived from a } \\
\text { verb to look. } \\
\text { 2. A process of looking for something or } \\
\text { someone. } \\
\text { 3. Face expression. } \\
\text { 4. Fashion and style. } \\
\text { 5. Image of a person especially if s/he is at- } \\
\text { tractive. (OLD) }\end{array}$ & $\begin{array}{l}\text { Equal to 4 and 5 } \\
\text { meanings. }\end{array}$ \\
\hline
\end{tabular}

To explain the usage of a word [beze] in Table 2 we need a historical context that led to the survival and active use of this word in Russian. This loanword originally was used in the meaning of a kiss $(1-2)$, which was preserved due to N.V. Gogol's novel "Dead Souls" (1853):

(1) Russian: "Позволь, душа, я тебе влеплю один безе. Уж вы позвольте, ваме превосходительство, поцеловать мне его. Да, Чичиков, уж ты не противься, одну безешку позволь напечатлеть тебе в белоснежную щеку твою!" (Gogol' 2017)

(2) English: "Let me imprint upon your cheeks a baiser or two. You will excuse me if I kiss him, will you not, your Excellency? No, do not resist me, Chichikov, but allow me to imprint at least one baiser upon your lily-white cheek." (Gogol')

To sum up, the first type of interaction results in a formal (orthographic and grammatical) and semantic adaptation of a loaned lexical unit to the structure of the recipient language and to the LPW of the language's native speakers. The cultural LPW is not only retained but also lexically enriched by new units, which in their turn have acquired the rules of the recipient language and can fulfil the cumulative and world-image constructive functions of the Russian language.

\subsection{Second interaction type}

The loanwords of the second interaction type demonstrate orthographic and grammatical assimilation but have disputable traces of a semantic assimilation. This type of interaction does not result in the same semantic assimilation of the loanwords as the first. In this type, English loanwords bring new semantics to the hostlanguage and the recipient LPW. The interaction of the second type includes loanwords whose loaning is motivated by the borrowing of a new concept or an idea that brings changes to the common course of life within a recipient culture. With such loanwords the LPW of a recipient language loans a fragment of another picture of the world (Aitalieva 2013:2) and is enriched by new culture-specific elements, which represent an element of "an alien worldview" (Aitalieva 2013: 3): Russ. 
каршеринг [karshering] — Eng. carsharing; Russ. скрапбукинг [skrapbuking] Eng. scrapbooking; Russ. спойлер [spojler] - Eng. spoiler; Russ. аутсорсинг [autsorsing] - Eng. outsourcing; Russ. cmapman [startap] — Eng. startup; Russ. аутстаффинг [autstaffing] - Eng. outstaffing ect.

This type of interaction can be seen in the word supermarket (Russ. супермаркет), which came into the Russian language from English, representing American culture. This word brought "an alien way of reality conceptualization" to the Russian world (Shmuner 2009: 140) and a new concept for Russian culture: "self-service as a form of trade" (Shmuner 2009: 140). This example belongs to the second interaction type between the Russian LPW and the English loanwords because it shows that loanwords bring new ways of reality conceptualization, and new ways of socio-cultural interaction between people. Such words represent not only the material objects, which were borrowed, but also the systems, ideas, and concepts that change both the life and worldview of the host-language community. Another such example is the word privatization (Russ. приватизаиия), which does not have such a material object to correspond to and does not implicate it, still this word is loaned "conceptually" as new, not typical for the recipient culture, and a way of organizing commercial relations.

The contrast between these English loanword examples is more obvious in the opposition with the words whose loaning is motivated by the corresponding material objects: Russ. плейер [player] — Eng. player; Russ. принтер [printer] — Eng. printer; Russ. cmennep [stepper] - Eng. stepper; Russ. cmenлep [stapler] — stapler; Russ. компьютер [computer] - Eng. computer; Russ. nроиесcop [protzessor] - Eng. processor etc.

To conclude, the loanwords of the second interaction type bring changes to the LPW by supplementing it with new ideas and concepts, which enables speakers of the host-language to broaden their worldview.

\subsection{Third Interaction Type}

The third interaction type, which we allocate through the synchronic and diachronic study of loanwords in Russian, is characterized by orthographic assimilation, rejection of semantic adaptation and active grammatical assimilation.

By the rejection of semantic adaptation we mean that new English loanwords entering the Russian language do not bring new objects, ideas, or concepts, but substitute the existing Russian words: n. кэжуал [kjezhual] — adj. повседневный [povsednevnyj]; n. andeйm [apdejt] — n. обновление [obnovlenie]; n. мастхэв [masthjev] - обязательно иметь [objazatel'no imet']. At the same time these words are actively adapting to Russian declination and conjunction paradigms and even producing new derivatives exploiting Russian morphemes, however they are stylistically marked and used in colloquial speech: n. кэжуальность [kjezhual'nost'] (in style) - повседневность [povsednevnost'], adj. кэжуальный [kjezhual'nyj] — equal to кэжуал; v. апдейтить [apdejtit'] - обновить [obnovit']; adj. мастхэвный [masthjevnyj], n. мастхэвность [masthjevnost] — 
equal to обязательно иметь. These two characteristics seem to be contradictory as one of the characteristics of the same lexical units shows the forcing of a hostlanguage, and the other one represents the loanwords integration tendency. Thus, on the grounds of these characteristics, in the third interaction type, we single out two groups of loanwords: loanwords with semantic substitution and loanwords with mixed morpheme structure.

Loanwords with semantic substitution are the borrowed lexical units that substitute already existing words in the host-language. These words neither mean new ideas and concepts, which broaden the worldview of the recipient language speakers, nor name new material objects borrowed from another culture (Table 3 ). They show a different semantic component that can be expressed by a Russian equivalent, which is sometimes an earlier loanword.

Table 3

Examples of English loanwords with equivalents in Russian

\begin{tabular}{|c|c|c|c|c|c|c|}
\hline English word & $\begin{array}{l}\text { English loan- } \\
\text { words in Cyril- } \\
\text { lic }\end{array}$ & $\begin{array}{c}\mathrm{RNC}^{2} \\
\text { entries }^{3}\end{array}$ & $\begin{array}{l}\text { RuTenTen }^{4} \\
\text { entries }\end{array}$ & $\begin{array}{l}\text { Russian } \\
\text { equivalent }\end{array}$ & $\begin{array}{l}\text { RNC } \\
\text { entries }\end{array}$ & $\begin{array}{c}\text { RuTenTen } \\
\text { entries }\end{array}$ \\
\hline coffee-break & кофе-брейк & $1-0$ & 4042 & \begin{tabular}{|l} 
перерыв \\
[pereryv]
\end{tabular} & $\begin{array}{c}2115- \\
4698\end{array}$ & 505676 \\
\hline developer & девелопер & $36-1012$ & 3785 & $\begin{array}{l}\text { paзработчик } \\
\text { [razrabotchik] }\end{array}$ & $206-760$ & 876980 \\
\hline draft & dpapm & $32-481$ & 2522 & $\begin{array}{l}\text { черновик [cher- } \\
\text { novik] }\end{array}$ & $340-133$ & 30682 \\
\hline pattern & паттерн & $25-4$ & 9830 & $\begin{array}{l}\text { шаблон [sha- } \\
\text { blon] }\end{array}$ & $299-98$ & 361912 \\
\hline $\begin{array}{l}\text { trench/ } \\
\text { trench coat }\end{array}$ & тренч & $10-30$ & 1323 & плаш [plashch] & $\begin{array}{c}2799- \\
369 \\
\end{array}$ & 162268 \\
\hline
\end{tabular}

The number of entries in the RNC are taken from general and journal subcorpora because they include the largest number of contexts in comparison with the oral or multimedia sub-corpora. The number of entries for each word in pairs in RNC and RuTenTen corpora (RuTenTen) demonstrates ongoing competition between the words in the Russian language use. We have decided to show the results from the two corpora because they embrace different texts from different resources. The table illustrates that RuTenTen comprises a considerably bigger number of Russian Internet texts and consequently provides more word entries. For example,

${ }^{2}$ RNC - Russian National Corpus. The first RNC entries column refers to the English loanwords exemplified in the second column of the table. The second RNC entries column refers to the Russian equivalent exemplified in the fifth column of the table.

${ }^{3}$ The first number in the column shows General sub-corpus entries, and the second number illustrates journal sub-corpora entries. The demonstrated data are retrieved from the RNC on 25.10.2019. (RNC)

${ }^{4}$ The first RuTenTen entries column refers to the English loanwords in Cyrillic column. The second RuTenTen entries column demonstrates the Russian equivalents exemplified in the fifth column of the table. 
in the case of coffee break, RNC shows only $0.02 \%$ of the RuTenTen data, though this loanword is widely used in Russian.

The analysis shows that some of the words were first loaned from English into Russian to define specific semantic aspects of an object that were not expressed by the Russian equivalents. For instance, кофе-брейк was borrowed to name a special type of a pause which happens during a conference for the participants to have a rest and usually drink coffee or tea. According to the Google Books Ngram Viewer data (see Picture 1), this word entered the Russian language in the mid-seventies but was not frequently used till the period of 1996-1999 when it demonstrates a sharp growth in usage.

Picture 1

Frequency of кофе-брейк usage in 1950-2008 in Russian

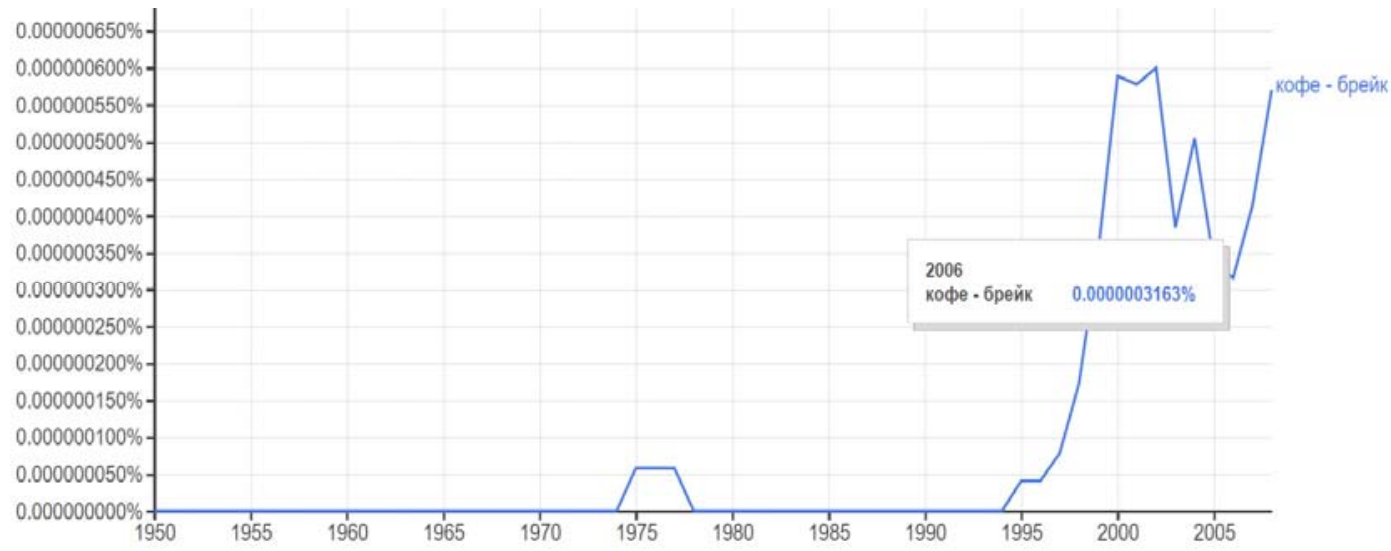

In the 'New Words and Meanings' dictionary based on the periodicals and newspapers of the 90-ss (Burtseva 2014), this word is defined as follows (3-4).

(3) Russian: Перерыв между заседаниями конференции, семинара, совещания, во время которого участникам предлагаются горячие напитки, бутерброды, печенье; кофе-пауза. (Burtseva 2014: 283)

(4) English: A pause between conference sections, seminars, meetings when participants are offered to get hot drinks, sandwiches, and cookies; coffee pause.

This definition reveals a Russian equivalent, or an earlier assimilated borrowing, to the English loan part break, which is naysa in the meaning of a break in Russian and can be used as a synonym to nepepbls provided in Table 3. The same dictionary defines coffee pause is an equivalent to coffee break (Burtseva 2014: 284).

Originally, coffee break means "a short rest from work in the morning or afternoon" (CD), according to both British and American English definitions of this word. This meaning roots to the mid-fifties in the USA when a break for a cup of coffee was introduced to a working day as a legal time for taking a rest (Hester 
2015). This meaning refers more to the original Russ. перекур [perekur] — Eng. smoking break, time out. The Russian кофе-брейк develops its context-defined semantics and gets to be used instead of the equivalent nерерыв in particular modern contexts (5-6).

(5) Russian: Если твои веки вот-вот сомкнутся, этот Volvo издаёт предупредительный звуковой сигнал и на приборной доске появляется изображение чашки, говорящее о том, что было бы неплохо остановиться на кофе-брейк или просто отдохнуть. (Panov 2013)

(6) English: If you are to close your eyes, Volvo gives you a warning sound and an image of a cup appears on the dash-board. It means that you should stop for a coffee break or take a rest.

Despite the fact that the word nepepble has much more entries in RNC and RuTenTen, the word кофе-брейк demonstrates a steady increase of frequency in broader contexts.

The existence of such words or "buzzwords" (Chen Huan 2017: 765) is grounded in a "language fashion" which is one of the universal reasons for loanword usage (Bogdanova 2015: 45, D'yakov 2001: 152, Krysin 2008, Szabolcs 2009: 48). Even though English loanwords bring new synonyms to the Russian language, they do not seem to be semantically assimilated in the sense that other loanwords undergo semantic adaptation. This results in the simultaneous existence of words of equal semantic value, which constitute a hybrid lexical mosaic of the Russian language when semantically equal words are competing for the same place in the lexical structure.

This process is visible in the language of Russian immigrants in English speaking countries. Surrounded by the English language, Russian speakers have to make a choice between two language structures: native and customary or foreign and practical. The words of a foreign language become practical abroad, but the components of a native language remain customary for expressing emotions and the attitude to the object. This leads to the production of words with mixed morpheme structure: English roots with Russian affixes.

In the history of Russian language studies words of mixed morpheme structure are called hybrid words. With respect to Russian, hybrid words are "foreign root derivatives with Russian affixes" (Zemskaya 2003). Such words were used in the speech of Russian immigrants in the USA in the 1990s, among whom 99,3\% said that they speak Russian and do not know English at all (Zemskaya 2003). (Table 4).

Obviously, such words with hybrid morphemic structure appear in speech when there is a close contact of both two languages and cultures. This is the case of Russian speakers living in the USA: the Russian community in the English language and American culture. 
Examples of hybrid words of Russian immigrants in the USA

Table 4

\begin{tabular}{|c|c|c|}
\hline $\begin{array}{c}\text { Source } \\
\text { word }\end{array}$ & $\begin{array}{l}\text { Cyrillic hybrid word, transliteration } \\
\text { and morpheme structure explanation }\end{array}$ & $\begin{array}{l}\text { Hybrid word } \\
\text { semantic }\end{array}$ \\
\hline \multirow[t]{2}{*}{ n. bedroom } & adj. трёхбедрумный [tryochbedroomniy] & \multirow{2}{*}{$\begin{array}{l}\text { a home with } \\
\text { three bedrooms }\end{array}$} \\
\hline & $\begin{array}{l}\text { mpëx (1 Russ. root) + бed (2 Eng.root) + pyм (3 Eng.root) + H } \\
\text { (Russ.adj.suffix) + blŭ (Russ. masculine adj. flection) }\end{array}$ & \\
\hline \multirow[t]{2}{*}{ v. to afford } & v. aфpфopdumь [affordyt'] & \multirow[t]{2}{*}{ to afford } \\
\hline & aфpфорд (Eng. root) $+u$ (Russ. verb suffix) $+m b$ (Russ. verb flection) & \\
\hline \multirow[t]{2}{*}{ n. cash } & v. окешить [okeshit'] & \multirow[t]{2}{*}{ to spend cash } \\
\hline & $\begin{array}{l}o \text { (Russ. verb prefix) }+\kappa e u \text { (Eng. root) }+u \text { (Russ. verb suffix) }+m b \\
\text { (Russ. verb flection) }\end{array}$ & \\
\hline
\end{tabular}

Nowadays, words of a similar morpheme structure appear in the Russian language in Russia as well (without the physical surroundings of an English language community or a culture corresponding to English as a native one). The cases enumerated in Table 5 show the hybrid nature of the words which Russian speakers make up with Russian derivatives; such words are constructed of loaned roots and Russian affixes. These lexical units are not caused by interference or bilingual usage of English words in Russian, as was described (Zemskaya 2003) when native Russian speakers were placed in an English language community and were creating words using the material of both languages. These are hybrid English origin words in the modern Russian language in Russia.

Table 5

Examples of hybrid English origin words in modern Russian in Russia

\begin{tabular}{|c|c|c|}
\hline $\begin{array}{l}\text { Source } \\
\text { word }\end{array}$ & $\begin{array}{l}\text { Cyrillic hybrid word, transliteration } \\
\text { and morpheme structure explanation }\end{array}$ & Hybrid word semantic \\
\hline \multirow{2}{*}{$\begin{array}{l}\text { v. to } \\
\text { parse }\end{array}$} & v. парсuть [parsit'] & \multirow{2}{*}{$\begin{array}{l}\text { to analyze data with } \\
\text { computer programs }\end{array}$} \\
\hline & $\begin{array}{l}\text { napc (Eng. root) }+u \text { (Russ. verb suffix) }+m b \text { (Russ. verb flec- } \\
\text { tion) }\end{array}$ & \\
\hline \multirow{2}{*}{$\begin{array}{l}\text { n. a pierc- } \\
\text { ing }\end{array}$} & adj. пирсинговый [pirsingovy] & \multirow{2}{*}{$\begin{array}{l}\text { adjective corresponding } \\
\text { to a piercing (piercing } \\
\text { shop, piercing salon) }\end{array}$} \\
\hline & $\begin{array}{l}\text { пирс (Eng. root) + инг (Eng. suffix) + ов (Russ. adj. suffix) + } \\
\text { ый (Russ. masculine adj. flection) }\end{array}$ & \\
\hline \multirow{5}{*}{$\begin{array}{l}\text { n. to } \\
\text { google }\end{array}$} & v. гуглить [guglit'] & \multirow{2}{*}{$\begin{array}{l}\text { to search for something } \\
\text { on the internet (not only } \\
\text { in a Google browser) }\end{array}$} \\
\hline & $\begin{array}{l}\text { гугл (Eng. root) + u (Russ. verb suffix) }+m b \text { (Russ. verb flec- } \\
\text { tion) }\end{array}$ & \\
\hline & v. нагуглить [naguglit'] & \multirow{2}{*}{$\begin{array}{l}\text { to have something } \\
\text { googled/found on the in- } \\
\text { ternet }\end{array}$} \\
\hline & $\begin{array}{l}\text { на (Russ. verb prefix) + гугл (Eng. root) }+u \text { (Russ. verb suf- } \\
\text { fix) }+m \text { ь (Russ. verb flection) }\end{array}$ & \\
\hline & $\begin{array}{l}\text { v. загуглить [zaguglit'] } \\
\text { за }+ \text { (Russ. verb prefix) }+ \text { гугл (Eng. root) }+u \text { (Russ. verb } \\
\text { suffix) }+ \text { mь (Russ. verb flection) }\end{array}$ & $\begin{array}{l}\text { to will have googled/ } \\
\text { found on the internet }\end{array}$ \\
\hline \multirow[t]{2}{*}{ n. a selfie } & v. селфить [selfit'] & \multirow[t]{2}{*}{ to take selfies } \\
\hline & $\begin{array}{l}\text { cendp (Eng. root) }+u \text { (Russ. verb suffix) }+m b \text { (Russ. verb flec- } \\
\text { tion) }\end{array}$ & \\
\hline
\end{tabular}


Evidently, every structural element of such hybrid lexical units has its own functional and semantic features, though the motivation of such lexical semantics formation is not clear; the Russian language gives birth to words whose meaning cannot be understood from their inner structure. For those Russian speakers who do not speak English the explanation of the hybrid words requires translation, which reveals the existence of Russian equivalents. The existence of hybrid morpheme structure words in the modern Russian language can be explained by the tendency of the host language to assimilate the English loanwords by making them more common for native Russian speakers.

Thus, by a hybrid LPW we mean a cultural LPW, which represents the worldviews and values of two lingua-culture communities simultaneously. It is the result of competition between loanwords and the recipient LPW. On the one hand, loanwords tend to be useful in a host language without changing their meaning, but by changing the recipient language lexical structure and introducing lexical units with already existing semantics that need not to be modified. On the other hand, a host language tries to adapt new words and concepts to the recipient language structure, to make them more common for the host language speakers. For this the host language uses its ability to subordinate the loanwords to its grammatical rules.

\section{Conclusion}

Through the example of the Russian language the synchronic and diachronic study revealed the existence of different interaction types between the loanwords and the recipient language picture of the world. The first interaction type is the loanwords adaptation to the host language: the LPW dominance over the borrowed lexical units. The second interaction type is the loanwords' dominance over the LPW, which results in bringing new objects, concepts and ideas to the host language. The third interaction type showed that loanwords are able to influence the change of the recipient language's verbal code of culture by substituting the existing lexical equivalents. However, the third interaction type also represents the rejection of the loanwords to be adapted to the recipient language and the LPW, and the language forcing this adaptation through its derivative ability. This interaction type demonstrates the development of the hybrid language picture of the world in the Russian language caused by an active process of English loanword adaptation and, thus, requires further thorough study and examination.

(C) Yulia M. Alyunina, Olga V. Nagel, 2020
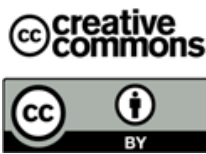

This work is licensed under a Creative Commons Attribution 4.0 International License https://creativecommons.org/licenses/by/4.0/ 


\section{REFERENCES}

Aitalieva, E. Zh. 2013. Yazykovaya Kartina Mira i Leksicheskie Zaimstvovaniya. [The Language Picture of the World and Lexical Borrowing. (In Russ.)]. Retrieved from: https://scienceforum.ru/2013/article/2013008198 [Last viewed: 12.01.18].

Bogdanova L.I. 2015. New words in interaction of languages and cultures. Russian Journal of Linguistics 2, 41-50.

Chen Huan. 2017. Buzzwords in Modern Russian and Chinese Newspapers: Origin, Semantics, Functions. Russian Journal of Linguistics 21 (4), 749-766. doi 10.22363/231291822017-21-4-749-766.

D'yakov, A. I. 2001. Derivatsionnaya Integratsiya Anglitsizmov v Russkom Yazyke Kontsa XX Veka v Funktsional'nom Aspekte [Derivational Integration of Anglicisms in Russian of the End of XX Century in a Functional Aspect. Ph.D. thesis. (In Russ.)].

Gabdreeva, N. V. \& Russko-Frantsuzskie Yazykovye Kontakty: Protsess Zaimstvovaniya i Assimilyatsii kak Sledstvie Mezhkul'turnoi Kommunikatsii, 1 (1), 221-232. [RussianFrench Language Contacts: Borrowing and Assimilation as a Result of an Intercultural Communication. Communicative Researches (In Russ.)].

Gogol', N. V. 2017. Mertvye Dushi. [Dead Souls. (In Russ.)]. Retrieved from: https://ilibrary.ru/text/78/index.html. [Last viewed: 08.06.18].

Gogol', N. V. 2008. Dead Souls. Retrieved from: https://www.weblitera.com/book/ ?id=29\&lng=1\&ch=8\&l=ru\#.W5nSPOhKg2w. [Last viewed: 08.06.18].

Khalevin, K. V. 2010a. Geneticheskie Kharakteristiki Inoyazychnykh Zaimstvovanii v Russkom Leksicheskom Prostorechii. Vestnik Cherepovetskogo Gosudarstvennogo Universiteta 3. 68-73. [Genetic Characteristics of Foreign Borrowings in the Russian Lexical Substandard Language. Bulletin Cherepovets State University. (In Russ.)].

Khalevin, K. V. 2010b. Osobennosti Adaptatsii Inoyazychnykh Zaimstvovanii v Russkom Leksicheskom Prostorechii. Vestnik Severnogo (Arkticheskogo) Federal'nogo Universiteta. Seriya: Gumanitarnye i Sotsial'nye Nauki 4. 82-86. [Peculiarities of Foreign Borrowings Adaptation in the Russian Colloquial Language Vocabulary. Vestnik of Northern (Arctic) Federal University. Series "Humanitarian and Social Sciences". (In Russ.)].

Haugen, E. 1950. The Analysis of Linguistic Borrowing. Language 26 (2). 210-231.

Hester, J. L. 2015. A Brief History of the Coffee Break. Citylab. Retrieved from: https://www.citylab.com/life/2015/09/a-brief-history-of-the-coffee-break/407782/. [Last viewed: 28.09.19].

Jaworski, S. 2014. Contact-induced changes in Polish morphology. Language Contact Around the Globe 12. 25-45.

Klement'eva, E. V. 2014. Adaptatsiya Inoyazychnykh Zaimstvovanii v Russkom Yazyke. Istoricheskaya i Sotsial'no-Obrazovatel'naya Mysl' 5. 260-263. [Foreign Loanwords: Adaptation to the Russian Language. Historical and Social-Educational Idea. (In Russ.)].

Krysin, L. P. 2008. Slovo v Sovremennykh Tekstakh i Slovaryakh: Ocherki o Russkoi Leksike i Leksikografii. Moscow: Znak. [Word in Contemporary Texts and Dictionaries. Sketches on Russian Lexis and Lexicography. (In Russ.)].

Levontina, I., Shmelev A. \& Zaliznjak A. 2012. Konstanty i Peremennye Russkoi Yazykovoi Kartiny Mira. Moscow: Liters. [Constants and Variables of the Russian Linguistic Picture of the World. (In Russ.)].

Lisogub, L. I. 2004. Osobennosti Foneticheskoi i Graficheskoi Assimilyatsii Anglitsizmov v Sovremennom Nemetskom Yazyke (na Materiale Ekonomicheskoi Terminosistemy). Vestnik Sumskogo gosudarstvennogo universiteta. Serija Filologicheskie nauki 4 (63). 11-17. [Features of Phonetic and Graphic Assimilation of Anglicisms in the Modern 
German Language (on the Material of the Economic Terminological System). Visnik Sums'kogo derzavnogo universitetu. Seria Filologicni nauki (In Russ.)].

Lukin, O. V. 2015. Novye Napravleniya Sovremennogo Yazykoznaniya (2-ya Polovina XX Veka - XXI vek). Yaroslavl': RIO YaGPU. [Modern Linguistics New Fields (2d Part of XX-XXI Century). (In Russ.)].

Mel'nikova A. A. 2006. Sintaksis Yazyka I Natsional'naya Spetsifika Sposoba Deyatel"nosti: Sotsial'no-Filosofskii Analiz. Izvestiya Rossiiskogo gosudarstvennogo pedagogicheskogo universiteta im. A.I. Gertsena 7 (21). 33-43. [Language Structure and Cultural Features of Activities: A Philosophical Anthropological Analysis. Izvestia: Herzen University Journal of Humanities \& Science. (In Russ.)].

Nagel', O. V. \& Koksharova, N. F. 2015. Ispol'zovanie Proizvodnykh Otsenochnykh Naimenovanii Litsa kak Vyrazhenie Kul'turnogo Yazykovogo Koda. Mezhdunarodnyi zhurnal prikladnykh i fundamental'nykh issledovanii 5. 728 - 733 [The Use of Derivative Evaluative Names as Manifestation of Cultural Language Code. International Journal of Applied and Fundamental Research. (In Russ.)].

Nagel', O. V. 2015. Derivatsionnaya Spetsifika Naimenovanii Litsa v Slavyanskikh Yazykakh (na Materiale Parallel'nogo Podkorpusa NKRYa). Rusin 3 (41). 226-240. [Derivation Peculiarities of Nominal Nouns in Slavic Languages (Based on the Parallel Subcorpus of the National Russian Corpus). Rusin. (In Russ.)].

Nechaeva, I. V. 2011. Aktual'nye Problemy Orfografii Inoyazychnykh Zaimstvovanii. [Essential Issues of Foreign Loanwords Orthography. Moscow: Azbukovnik. (In Russ.)].

Panov, D. 2013. City Cowboy. Diesel Volvo V40 test-drive. RBK Daily 182 (1715). [Gorodskoj kovboj. Test-draiv dizel'nogo Volvo V40 Cross Country. RBK Daily. (In Russ.)] Retrieved from: https://books.google.ru/. [Last viewed: 01.10.19].

Poplack, Sh., Sankoff, D. \& Miller, Ch. 1988. The Social Correlates and Linguistic Processes of Lexical Borrowing and Assimilation. Linguistics 26. 47-104.

Popova Z. D. 2004. Sintaksicheskii Kontsept i Mezhkul'turnaya Kommunikatsiya. Vestnik Voronezhskogo Gosudarstvennogo Universiteta. Seriya: Lingvistika i Mezhkul'turnaya Kommunikatsiya 2. 27-31. [Syntactic Concept and Intercultural Communication. Proceedings of Voronezh State University. Series: Linguistics and intercultural communication. (In Russ.)].

Rivlina, A. 2015. Bilingual Creativity in Russia: English-Russian Language Play. World Englishes 3 (34). 436-455.

Serebrennikova, A. N. 2014. Miromodeliruyushchaya Funktsiya Prostranstvennoi Leksiki v Prezentatsionnykh Tekstakh Universiteta. Vestnik Nauki Sibiri 4 (14). 196-201. [World Image Constructive Function of Spatial Lexis in University Presentations Texts. Siberian Journal of Science. (In Russ.)].

Sharifian, F. 2017. Cultural Linguistics. Cultural Conceptualisations and Language. Amsterdam: John Benjamins Publishing.

Shmuner, A. S. 2009. Zaimstvovanie kak Otrazhenie Vzaimodejstvija Jazykovyh Kartin Mira (Na Materiale Russkogo, Anglijskogo i Japonskogo Jazykov). Vestnik Moskovskogo gosudarstvennogo oblastnogo universiteta. Seria: Lingvistika 1. 136-141. [A Borrowing as a Reflection of the Langueges' Worldview Interaction. Bulletin of the Moscow Region State University. Series: Linguistic. (In Russ.)].

Szabolcs, J. 2009. The Integratoin of English Loanwords in Russian: An Overview of Recent Borrowings. Studia Slavica 55. 45-65.

Tolstaya, S. 2007. K Ponyatiyu Kul'turnykh Kodov. Sbornik Statei k 60-letiyu Al'berta Kashfulovicha Baiburina. Studia Ethnologica 23-31. [To the Cultural Codes Determination. Studia Ethnologica, Collection of Articles Devoted to the 60-s Anniversary of Al'bert Kashfulovich Bajburin. (In Russ.)]. 
Tolstoi, N. I. 1995. Yazyk i Narodnaya Kul'tura: Ocherki po Slavyanskoi Mifologii i Etnolingvistike. Moscow: Indrik. [Language and Folk Culture. Sketches on Slavic Mythology and Ethnolinguistics. (In Russ.)].

Veisbergs, A. 2006. Systemic and Structural Changes in Latvian as a Result of Recent English Influence. Journal of Baltic Studies 4(37). 467-481.

Vereshchagin, E. M. 1980. Lingvostranovedcheskaya Teoriya Slova. Moscow: Ripol Classic. [Linguistic and cultural Theory of a Word. (In Russ.)].

Vorob'eva, S. V. 2009. Grammaticheskaya Assimilyatsiya Noveishikh Anglitsizmov v Russkom Yazyke. Vestnik Moskovskogo Gosudarstvennogo Lingvisticheskogo Universiteta. Seriya: Filologiya 9: Filologija 5 (42). 178-186. [Grammatical Assimilation of the Recent Anglicisms in Russian. Moscow State University Bulletin. Series 9: Philology. (In Russ.)].

Zemskaya, E. A. 2003. O Yazyke Russkogo Zarubezh'ya. Slovenski Knjižni Jezik - Aktualna Vprašanja in Zgodovinske Izkušnje 20. 95-106. [About Language of Russian Immigrants. Slovenski Knjižni Jezik - Aktualna Vprašanja in Zgodovinske Izkušnje. (In Russ.)].

\section{DICTIONARIES AND CORPORA}

Bol'shoi Entsiklopedicheskii Slovar'. 1993. [Big Encyclopedic Dictionary. Moscow: Sovetskaja Jenciklopedija. (In Russ.)]. Retrieved from: https://www.twirpx.com/file/1389507/. [Last viewed: 28.07.18]. CD — Cambridge Dictionary. Retrieved from: https://dictionary.cambridge.org/ru/. [Last viewed: 19.09.18].

Dictionnaire Français en Ligne Gratuit. Retrieved from: http://www.le-dictionnaire.com/. [Last viewed: 18.06.18]. DUDEN — German Language Dictionary. Retrieved from: https://www.duden.de/. [Last viewed: 12.06.19]. Merriam-Webster Dictionary. Retrieved from: https://www.merriam-webster.com/dictionary/window. [Last viewed: 15.09.18].

Burtseva, T. N. (eds.) 2014. Novye Slova i Znacheniya. Slovar'-Spravochnik po Materialam Pressy i Literatury 90-kh Godov XX Veka. Vol. 1. Saint-Petersburg: Institute of Linguistic Research of Russian Academy of Science: Dmitrij Bulanin. [New Words and Meanings: Dictionary-Manual on the Materials of Press and Fiction of 90-ss of the XX Century. (In Russ.)].

OLD - Oxford Learner's Dictionary. Retrieved from: https://www.oxfordlearnersdictionaries.com/. [Last viewed: 23.09.18]. RNC - Russian National Corpus. Retrieved from: http://ruscorpora.ru/new/. [Last viewed: 25.10.19]. RuTenTen. Sketch Engine. Retrieved from: https://www.sketchengine.eu/rutenten-russian-corpus/. [Last viewed: 25.10.19].

Shaposhnikov, A. K. 2010. Etimologicheskii Slovar' Sovremennogo Russkogo Yazyka. Vol. 1. Moscow: Flinta, Nauka. [Modern Russian Language Etymology Dictionary. (In Russ.)].

Shaposhnikov, A. K. 2010a. Etimologicheskii Slovar' Sovremennogo Russkogo Yazyka. Vol. 2. Moscow: Flinta, Nauka. [Modern Russian Language Etymology Dictionary. (In Russ.)].

Slovar' Academic. Retrieved from: https://dic.academic.ru/. [Last viewed: 07.08.18].

TSOO - Tolkovyi Slovar' Ozhegova Onlain. [Ozhegov Definition Dictionary Online. (In Russ.)]. Retrieved from: http://slovarozhegova.ru/word.php?wordid=27864. [Last viewed: 15.07.18].

\section{Article history:}

Received: 10 October 2019

Revised: 18 November 2019

Accepted: 25 November 2019 


\section{История статьи:}

Дата поступления в редакцию: 10 Октября 2019

Дата принятия к печати: 25 ноября 2019

\section{Bionote:}

YULIA M. ALYUNINA, PhD student at the Department of Foreign Languages at RUDN University completing her Doctoral dissertation. She is a current participant of full employment PhD program at RUDN University, a holder of a grant "Scholarship of the Russian Federation President for Studying Abroad" for a research internship at the University Lumière Lyon 2 in France (2018-2019). Her research interests include English loanwords in Russian, modern English language and culture and language contacts.

\section{Contact information:}

E-mail: aliunina-yum@rudn.ru

Address: 6 Miklukho-Maklaya St., Moscow, 117198

ORCID: 0000-0002-4970-5584

OLGA V. NAGEL, Professor at National Research Tomsk State University. She possesses a Doctorate Degree in the Theory of Language and the Russian Language and conducts research studies in Russian derivational morphology, language processing and bilingual aspects of language acquisition and use. She is also a Leading Research Fellow at the Linguistic Anthropology Laboratory whose activity is focused on the study of language interactions within speakers' minds in the context of multicultural communication.

\section{Contact information:}

E-mail: nagel.olga@mail.tsu.ru

Address: 34 Lenin Avenue, Tomsk, 634050

eLibrary SPIN-код: 9328-0166

\section{Сведения об авторах:}

АЛЮНИНА ЮЛИЯ МАТВЕЕВНА - аспирант кафедры иностранных языков филологического факультета Российского университета дружбы народов, участник программы «Аспирантура полного дня» (инновационная программа РУДН, направленная на развитие академической карьеры и вовлечение аспирантов в мировое научное сообщество, 2017-2018 гг., 2018-2019 гг.), обладатель гранта «Стипендия Президента РФ для обучения за рубежом» для прохождения научной стажировки в университете Lumière Lyon 2 во Франции (2018-2019). Сфера научных интересов лежит в области англицизмов в русском языке, английского языка и культуры в современном мире, языковых контактов.

\section{Контактная информация:}

E-mail: aliunina-yum@rudn.ru

Aдрес: 117198, г. Москва, ул. Миклухо-Маклая, 6

ORCID: 0000-0002-4970-5584 eLibrary SPIN-код: 1972-7723 
ОЛЬГА ВАСИЛЬЕВНА НАГЕЛЬ - профессор кафедры английской филологии в Национальном исследовательском Томском государственном университете. Научные интересы О.В. Нагель отражены в докторской диссертации и лежат в сфере деривационной системы русского языка, обработки языка и билингвальных аспектов усвоения и использования языка. О.В. Нагель также является ведущим научным сотрудником Лаборатории лингвистической антропологии, в рамках которой ведутся исследования межязыкового взаимодействия в сознании билингвов в условиях мультикультурной коммуникации.

\section{Контактная информация:}

E-mail: nagel.olga@mail.tsu.ru

Aдрес: 634050, г. Томск, просп. Ленина, 34

eLibrary SPIN-код: 9328-0166 